\title{
GEOLOGIA DA PORÇAO NORTE DO GREENSTONE BELT DE GUARINOS, GOIÁS
}

\author{
HARDY JOST, RAUL MINAS KUYUMJIAN, ANA LUIZA SABÓIA DE FREITAS, ANDRÉ LUIZ LIMA COSTA, \\ CARLOS TADEU C. NASCIMENTO, FLÁVIO DE MORAIS VASCONCELOS. LUIZ GALOTTI NETO, MARIA \\ CEICILENE ARAGÃO MARTINS, MOISÉS NAVES CARVALHO, VALERIA CERQUEIRA CONDE
}

\begin{abstract}
The Guarinos greenstone belt is one of the three Archaean volcano-sedimentary rock assemblages of Crixás, Goiás, and its northern half was maped by the authors in 1992. The belt was intruded by a tonalite of the Caiamar Complex in the west, has a transcurrent fault contact with gneisses of the Moquém Block in the east and north, and is tectonically covered by Late Proterozoic metassedimentary rocks of the Araxá Group in the south. Its northeastern portion was intruded by a trondhjemite. Rocks of the belt (Guarinos Group) are grouped, from base to top, into the Serra do Cotovelo Formation (metakomatiites), Serra Azul Formation (tholeiitic metabasalts), São Patricinho Formation (detrital metassedimentary rocks), Aimbé Formation (banded iron formations, metaconglomerates and metahydrothermalites), and the Cabaçal Formation, which is further subdivided into a lower sub-unit (carbonaceous phyllites, locally metachert and banded iron and manganese formations), and an upper sub-unit (rythmic metashales and metasiltites). The supracrustais are folded into a normal and horizontal antiform in the south, which gives place to westerly dipping inverse antiforms in the north and east. The trondhjemite intrusion in the northeastern portion of the belt deformed the supracrustal rocks into a dome. Primary structures in metavolcanic and metasedimentary rocks indicate that the stratigraphic sequence of the greenstone belt is overturned, due to early northward verging nappes, followed by Late Proterozoic, easterly verging folding. Regional metamorphism took place under greenschist facies conditions. Contact metamorphic parageneses formed under hornblende hornfels and albite-epidote hornfels facies, respectively in contact with the western tonalite and the northeastern trondhjemite. Mylonites are of greenschist to lower amphibolite facies. Mineral resources in the area comprise gold and banded iron and manganese formations, under several
\end{abstract} modes of occurrence.

Keywords: Archaean, Goiás, greenstone belt, geology, Guarinos.

RESUMO O greenstone belt de Guarinos é uma das três faixas de rochas supracrustais arqueanas da região de Crixás, Goiás, cuja metade norte foi mapeada pelos autores em 1992. As supracrustais limitam-se com um tonalito intrusive do Complexo Caiamar a oeste, por falha transcorrente com gnaisses do Bloco do Moquém a leste e norte, com rochas metassedimentares neoproterozóicas a sul. Na sua porção nordeste, a seqüência foi intrudida por um corpo de trondhjemito. As supracrustais (Grupo Guarinos) foram divididas, da base para o topo, nas formaçoes Serra do Cotovelo (metakomatiitos), Serra Azul (metabasaltos toleifticos), São Patricinho (rochas metassedimentares detríticas rítmicas), Aimbé (formacões ferríferas, metaconglpmerados e metahidrotermalitos) e Cabaçal, a qual contem uma subunidade inferior (filhos carbonosos, subordinadamente metachert e formações ferríferas e manganesíferas) e uma superior (metafolhelhos, metassiltitos e metarenitos finos e rítmicos). A estrutura regional do greenstone belt de Guarinos é, a sul, um antiforme normal e horizontal que grada, para norte e leste, para um antiforme inverso de superfície axial mergulhante para oeste. A intrusão trondhjemítica da porção nordeste estruturou as rochas supracrustais em um domo alongado. Estruturas primárias vulcânicas e sedimentares indicam que a seqüência estratigrafica do Grupo Guarinos está invertida, devido à formação de nappes com vergência norte. Durante o Proterozóico Superior ocorreu deformação com vergência leste. Metamorfismo regional ocorreu em fácies xisto verde. Metamorfismo termal ocorreu nos contatos com o tonalito de oeste e trondhjemito de nordeste, respectivamente nas fácies hornblenda hornfelse e albita-epidoto hornfelse. Milonitos são das fácies xisto verde a anfibolito inferior. Os recursos minerais da área compreendem ouro e formações ferríferas e manganesíferas, sob diversos modos de ocorrência.

Palavras-chaves: Arqueano, Goiás, greenstone belt. Geologia, Guarinos.

INTRODUÇÃ̃ Mais de uma década decorreu desde o reconhecimento da região de Crixás-Pilar de Goiás, Goiás, (Fig. 1) como um segmento crustal arqueano com associações do tipo granito-greenstone belt. Em 1985, o Instituto de Geociências da Universidade de Brasília iniciou um programa de mapeamento sistemático da região, na escala 1:25.000. O primeiro alvo foi a faixa de Pilar de Goiás (Danni, et.al 1986), seguido da faixa Guarinos, executado em duas etapas. A primeira, realizada em 1987, visou a porção sul (Jost \& Ferreira 1987) e a segunda, em 1992, a porção norte.

Esse trabalho descreve os resultados do mapeamento geológico da metade norte do greenstone belt de Guarinos (Fig. 2), realizado como parte do treinamento dos formandos do Curso de Geologia da Universidade de Brasília.
GEOLOGIA REGIONAL Algumas áreas do Maciço Mediano de Goiás (Almeida 1968) consistem de associações arqueanas de greenstone belts e complexos granitognáissicos, tais como a de Crixás-Pilar de Goiás (Fig. I). As rochas arqueanas de Crixás afloram no interior de uma janela esculpida em rochas supracrustais do Proterozóico e compreendem três faixas vulcanossedimentares subparalelas (Crixás, Guarinos e Pilar de Goiás), orientadas segundo norte-sul e separadas por complexos dômicos granitognáissicos (Anta, Caiamar, Moquém e Hidrolina) (Danni \& Ribeiro 1978, Sabóia 1979).

O greenstone belt de Guarinos limita-se, a leste, com gnaisses do Bloco Moquém (Danni \& Ribeiro 1978, Vargas 1992, Jost et.al 1994a), por falhas. A oeste, as supracrustais limitam-se com urri tonalito intrusivo (Jost et.al 1994b) de idade $\mathrm{Rb} / \mathrm{Sr}$ mínima de $2,9 \mathrm{Ga}$ (Tassinari \& Montalvão 


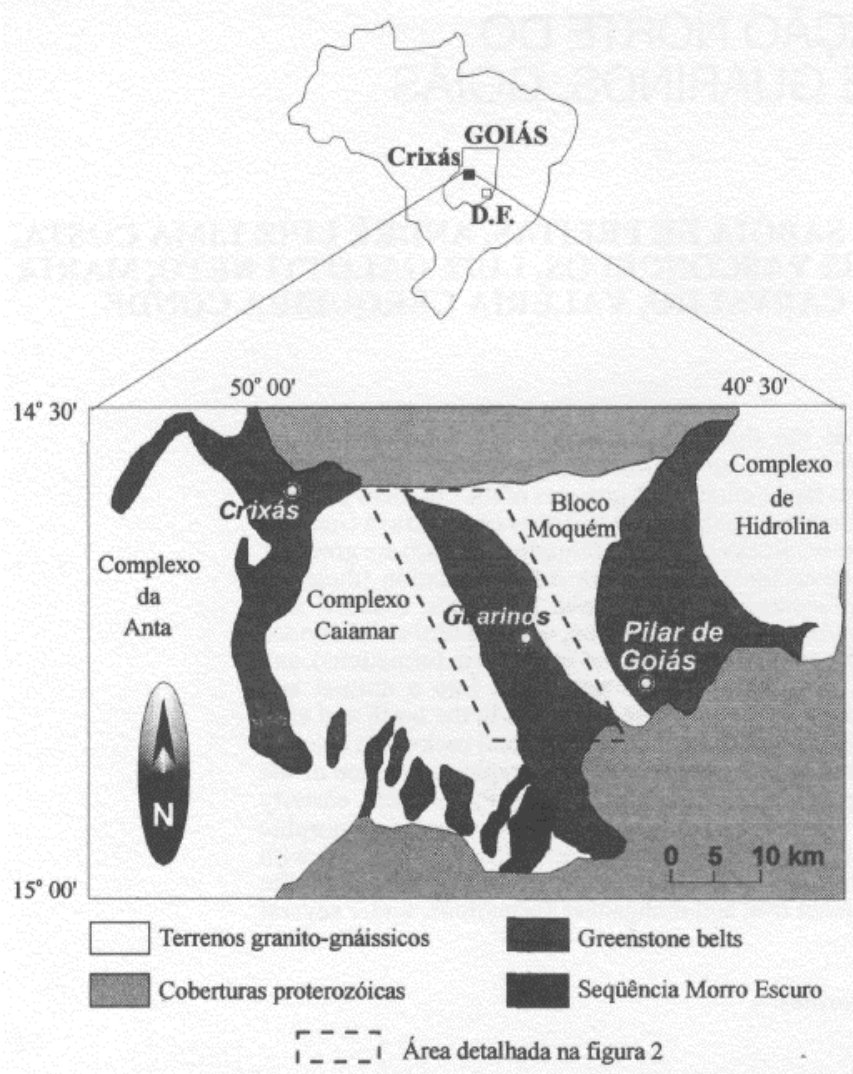

Figura 1 - Localização e esboço geológico da região arqueana de Crixás, Goiás (modificado de Jost \& Oliveira 1991)

Figure 1 - Location and schematic geologic map of the Crixás Archaean region, Goiás (modified from Jost \& Oliveira 1991)

1980, Montalvão 1985, Vargas 1992), pertencente ao Complexo Caiamar.

A nordeste, as rochas do greenstone belt de Guarinos foram intrudidas por um corpo irregular de trondhjemito. A sul e norte, as rochas arqueanas estão parcialmente recobertas por rochas metassedimentares do NeoPro-terozóico, mediante um contato tectônico marcado por milonitos com baixo mergulho, respectivamente para sul e norte.

Aluviões, colúvios, pavimentos detríticos e crostas lateríticas modernas são raras e recobrem as unidades mais antigas em diverdsas cotas.

ESTRATIGRAFIA A porção setentrional do greenstone belt de Guarinos (Fig. 2) tem cerca de $150 \mathrm{~km}^{2}$, orienta-se segundo $\mathrm{N} 10^{\circ} \mathrm{W}$ e tem $6 \mathrm{~km}$ de largura média e cerca de $20 \mathrm{~km}$ de comprimento, extendendo-se, para sul, além dos limites da área mapeada. A primeira subdivisão estratigráfica destas supracrustais foi proposta por Danni \& Ribeiro (1978), posteriormente reformulada por Sabóia (1979) e redefinida por Jost \& Oliveira (1991). De acordo com a última proposta, as supracrustais estão reunidas no Grupo Guarinos, o qual se subdivide, da base para o topo, nas formações Serra do Cotovelo, Serra Azul, São Patricinho, Aimbé e Cabaçal.

A Formação Serra do Cotovelo tem, na área mapeada, uma espessura real inferior a $100 \mathrm{~m}$ e consiste de metakomatiitos com intercalações de formações ferríferas da fácies oxido. A unidade ocorre apenas na porção noroeste da área, sob a forma de cunhas e lentes imbricadas em metabasaltos da Formação Serra Azul, nas imediações do contato com rochas do Complexo Caiamar.
A Formação Serra Azul perfaz a maior área do Grupo Guarinos e é representada por cerca de $600 \mathrm{~m}$ de espessura de metabasaltos que ocorrem em duas faixas coalescentes em direção a norte (Fig. 2). Os metabasaltos contornam, pelo leste e oeste, uma faixa contendo as rochas metassedimentares sobrepostas, com as quais o contato é parcialmente normal a sul e dominantemente tectônico a norte. Intercalações de filhos carbonosos originalmente incluídas por Jost \& Oliveira (1991) na Formação Serra Azul, são, de fato, imbricações de parte de unidades metassedimentares estratigrafícamente superiores.

A Formação São Patricinho tem uma espessura variável entre 30 e $100 \mathrm{~m}$, é descontínua e aflora apenas nas porções meridionais da área (fig. 2). A unidade consiste de rochas metassedimentares detríticas, cujo contato com os metabasaltos da Formação Serra Azul é, em geral, tectônico, mas localmente brusco.

A Formação Aimbé possui uma espessura média de $70 \mathrm{~m}$ e compreende formações ferríferas, rochas metassedimentares detríticas e metahidrotermalitos. Na porção sul da área, essa formação aflora em ambos flancos de uma estrutura antiformal (Fig. 2), e recobre tanto metabasaltos da Formação Serra Azul quanto rochas metassedimentares da Formação São Patricinho, por contatos não tectônicos, interpretados por Jost, et al (1994c) como uma provável discordância. A norte de Guarinos, essa formacão ocorre em lentes tectonicamente imbricadas em rochas das formações Serra Azul e Cabaçal.

A Formação Cabaçal tem uma espessura real aproximada é de 400 m, como já estimado por Jost \& Oliveira (1991) e é composta por rochas metassedimentares distribuídas em dois membros. O Membro Inferior consiste de filitos carbonosos com esporádicas intercalações lenticulares métricas de formações ferríferas e manganesíferas e níveis decamétricos de metabasaltos, localizados preferencialmente na porção inferior. A passagem das formações ferríferas da Formação Aimbé para os filitos carbonosos é transicional, como sugerem as alternâncias, em geral decimétricas, de ambos tipos de rocha ao longo de um curto intervalo. $\mathrm{O}$ Membro Superior consiste de metassiltitos e metafolhelhos, comumente rítmicos, com raros filitos carbonosos e derrames básicos. A passagem do Membro Inferior para o Superior é brusca. A presença, ainda que rara e escassa, de fragmentos milimétricos a centimétricos de filito carbonoso em alguns níveis de metassiltito próximos à base do Membro Inferior sugerem que o mesmo provavelmente repousa sobre o Membro Inferior ao longo de uma discordância erosiva.

\section{PETROGRAFIA Formação Serra do Cotovelo A}

Formação Serra do Cotovelo compreende rochas metaultramáfícas com intercalações de formações ferríferas. As rochas metaultramáficas são talco xistos verde amarelados a amarelos e foliados. Nas imediações do Complexo Caiamar, estas rochas possuem, além de talco, também carbonato e cristais centimétricos de actinolita, sugerindo metamorfismo e metassomatismo de contato. A textura dominante dessas rochas é lepidoblástica fina, localmente nematoblástica e porfiroblástica. $\mathrm{O}$ mineral essencial é o talco, acompanhado de proporções subordinadas de clorita e carbonato e, localmente, traços de serpentina, actinolita, turmalina, rutilo e ilmenita. A ausência de texturas e estruturas vulcânicas não permite provar a sua origem vulcânica, o que porém é indicado pelas intercalações de formações ferríferas.

As formações ferríferas são raras e ocorrem em camadas bandadas de espessura métrica, cor preta a marrom quando inalteradas, parda ou amarela e friáveis quando intemperizadas. Sua textura é granoblástica, comumente em mosaico, e poiquiloblástica, e consistem de magnetita e/ou hematita, subordinadamente quartzo. 


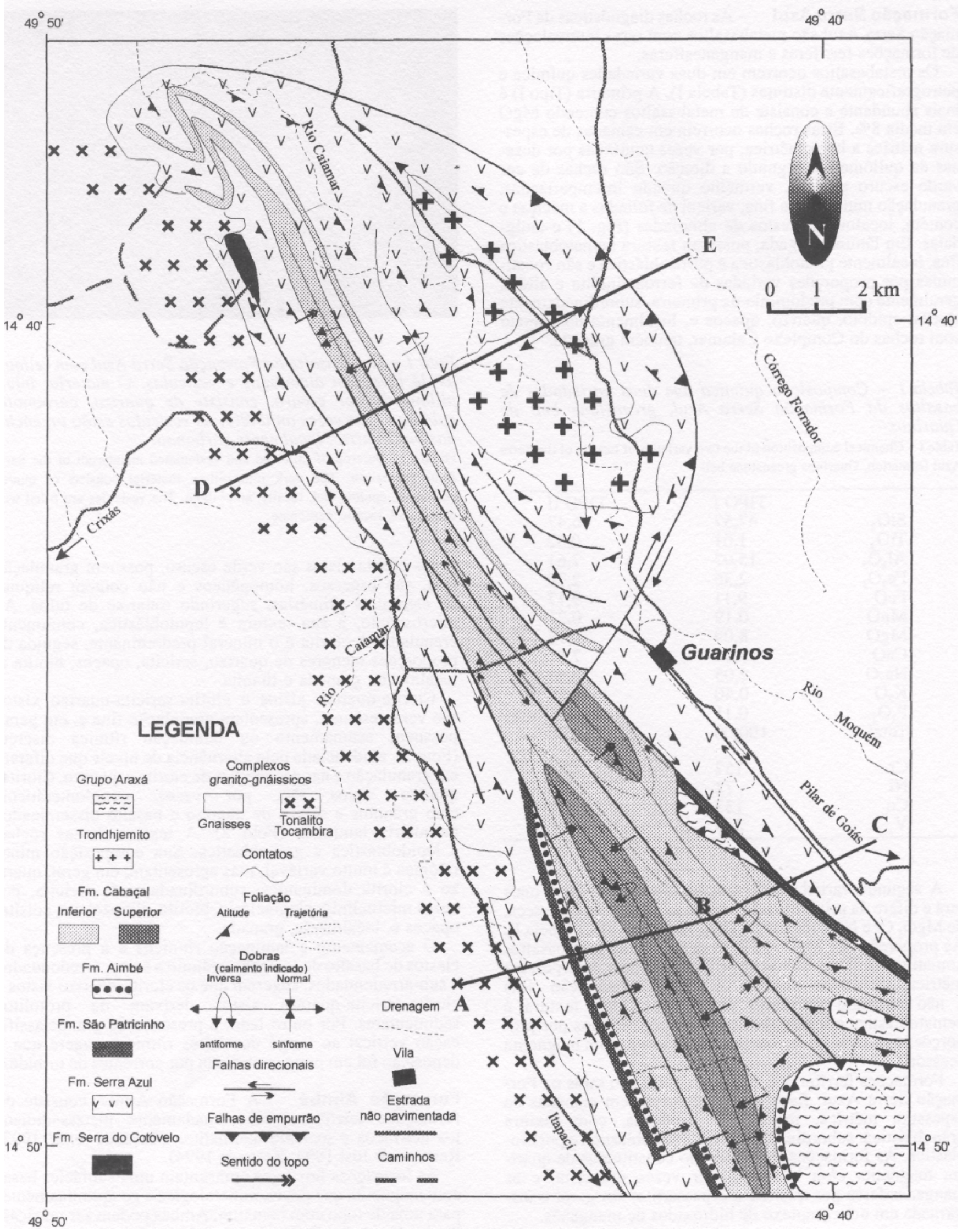

Figura 2 - Mapa geológico da metade norte do greenstone belt de Guarinos, Goiás. A-B-C e D-E correpondem à localização das seções transversais da figura 10

Figure 2 - Geologic map of the northern half of the Guarinos greenstone belt, Goiás. A-B-C and D-E are the location of the cross-sections showed in figure 10 
Formação Serra Azul As rochas diagnosticas da Formação Serra Azul são metabasaltos com raras intercalações de formações ferríferas e manganesíferas.

Os metabasaltos ocorrem em duas variedades química e petrograficamente distintas (Tabela I). A primeira (Tipo I) é mais abundante e consiste de metabasaltos contendo $\mathrm{MgO}$ em média $8 \%$. Estas rochas ocorrem em camadas de espessura métrica a hectométrica, por vezes contínuas por dezenas de quilômetros segundo a direção. São rochas de cor verde escuro a claro, vermelho quando intemperizadas, granulação muito fina a fina, variam de foliadas a maciças e contém, localmente, restos de almofadas (Fig. 1) e amigdalas. Em lâmina delgada, possuem textura nematoblástica fina, localmente granoblástica e porfiroblástica e são constituídas por proporções variadas de ferroactinolita e albita, geralmente com predomínio da primeira, subordinadamente clorita, epidoto, quartzo, opacos e, localmente no contate com rochas do Complexo Caiamar, também granada.

Tabela I-Composição química das duas variedades de basaltos da Formação Serra Azul, greenstone belt de Guarinos

Table I - Chemical composition of the two varieties of basalts of the Serra Azul formation, Guarinos greenstone belt

\begin{tabular}{lrr}
\hline & TIPO I & TIPO II \\
$\mathrm{SiO}_{2}$ & 47,57 & 46,47 \\
$\mathrm{TiO}_{2}$ & 1,01 & 0,52 \\
$\mathrm{Al}_{2} \mathrm{O}_{3}$ & 15,07 & 7,61 \\
$\mathrm{Fe}_{2} \mathrm{O}_{3}$ & 2,36 & 2,79 \\
$\mathrm{FeO}$ & 9,11 & 9,17 \\
$\mathrm{MnO}$ & 0,19 & 0,21 \\
$\mathrm{MgO}$ & 8,09 & 24,76 \\
$\mathrm{CaO}$ & 13,98 & 7,61 \\
$\mathrm{Na}$ & 2,05 & 0,54 \\
$\mathrm{~K}_{2} \mathrm{O}$ & 0,40 & 0,25 \\
$\mathrm{P}_{2} \mathrm{O}_{5}$ & 0,11 & 0,03 \\
$\mathrm{Total}$ & 100,00 & 100,00 \\
$\mathrm{Cr}$ & 152 & 3054 \\
$\mathrm{Ni}$ & 72 & 1228 \\
$\mathrm{Co}$ & 133 & 121 \\
$\mathrm{~V}$ & 340 & 171 \\
\hline
\end{tabular}

A segunda variedade de metabasaltos (Tipo II) é mais rara e difere da primeira pelo conteúdo maior, em base seca, de $\mathrm{MgO}, \mathrm{Cr}$ e Ni, e menor de $\mathrm{TiO}_{2}, \mathrm{Al}_{2} \mathrm{O}_{3}$, e $\mathrm{CaO}$, (Tabela I). As proporções de $\mathrm{MgO}>18 \%$ os define como metabasaltos komatí́ticos. Estas rochas ocorrem em lentes de espessura métrica, possuem cor verde clara, granulação fina e não mostram estruturas primárias. A sua textura é nematoblástica e lepidoblástica e são constituídos por proporções similares de ferroactinolita e clorita, com magnetita acessória.

Formações ferríferas e manganesíferas são raras na Formação Serra Azul. Estas rochas ocorrem em camadas de espessura métrica, maciças a bandadas, com textura granoblástica, subordinadamente poiquiloblástica e porfiroblástica. As formações ferríferas são constituídas de quartzo, magnetita e/ou hematita, por vezes grunerita, e as manganesíferas por quartzo e espessartita, em geral transformada em um complexo de hidróxidos de manganês.

Formação São Patricinho As rochas da Formação São Patricinho são clorita xistos, clorita-quartzo xistos e clorita-sericita-quartzo xistos. As relações entre esses litotipos é, ainda, desconhecida e sua origem é, em parte sedimentar, em parte provavelmente também tufácea básica.

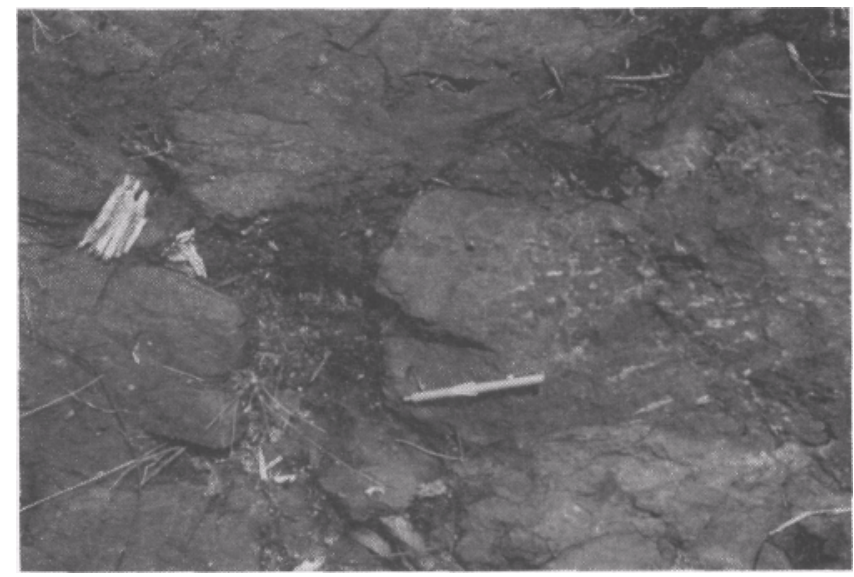

Foto 1 - Metabasalto da Formação Serra Azul com relíquias de lavas em almofadas e vesículas. $O$ material interpillow, de cor escura, consiste de quartzo, carbonato, epidoto e, por vezes anfibólio. As vesículas estão preenchidas por quartzo, localmente carbonato

Photo 1 - Outcrop of pillowed and vesiculated metabasalt of the Serra Azul Formation. The dark inter-pillow material consists of quartz, carbonate, epidote and, locally, amphibole. The vesicules are filled with quartz and, locally, carbonate

Os clorita xistos são verde escuro, possuem granulação fina, são espessos, homogêneos e não contém relíquias de estruturas primárias, sugerindo tratar-se de tufos. Ao microscópio, a sua textura é lepidoblástica, comumente crenulada. A clorita é o mineral predominante, seguida de proporções menores de quartzo, sericita, opacos, biotita e, localmente, granada e titanita.

Clorita-quartzo xistos e clorita-sericita-quartzo xistos são verde escuros, apresentam granulação fina e, em geral, possuem acamamento ou laminação rítmica discreta (Foto 2), evidenciada pela alternância de níveis que diferem em granulação e nas proporções de clorita e quartzo. Cloritaquartzo xistos são, por vezes, conglomeráticos, com granules e seixos de quartzo e basalto disseminados na matriz laminada (Foto 2 ). A textura dessas rochas é lepidoblástica a granoblástica. Sua composição mineralógica é muito variável, mas apresentam, em geral, quartzo e clorita dominantes, subordinadamente sericita, por vezes microclínio, plagioclásio, biotita, clinozoisita, zoisita, opacos e, localmente, granada.

$\mathrm{O}$ acamamento e laminação rítmicos e a presença de clastos de basalto do tamanho grânulo a seixo, arredondados a sub-arredondados, sugerem que os clorita-quartzo xistos e clorita-sericita-quartzo xistos derivam de protolitos sedimentares. Por outro lado, a presença de granoclassificação vertical ao longo dos leitos rítmicos sugere que a deposição foi em parte controlada por correntes de turbidêz.

Formação Aimbé A Formação Aimbé consiste de formações ferríferas, subordinadamente metassedimentos detríticos e metahidrotermalitos (Resende et.ai 1993, Resende \& Jost 1994, Resende 1994).

As formações ferríferas apresentam uma subfácies basal com magnetita que grada, mineralogica e geoquimicamente, para uma de topo com hematita. Ambas podem ser maciças, laminadas ou bandadas. Laminação e bandamento são dados pela alternância de óxidos de ferro e muscovita (Foto 3). Quartzo, quando presente, raramente atinge $5 \%$.

As fácies detríticas são raras e consistem de nnetaconglomerados e muscovita xistos. Os metaconglomerados (Foto 4) ocorrem em lentes situadas na base da subfácies 


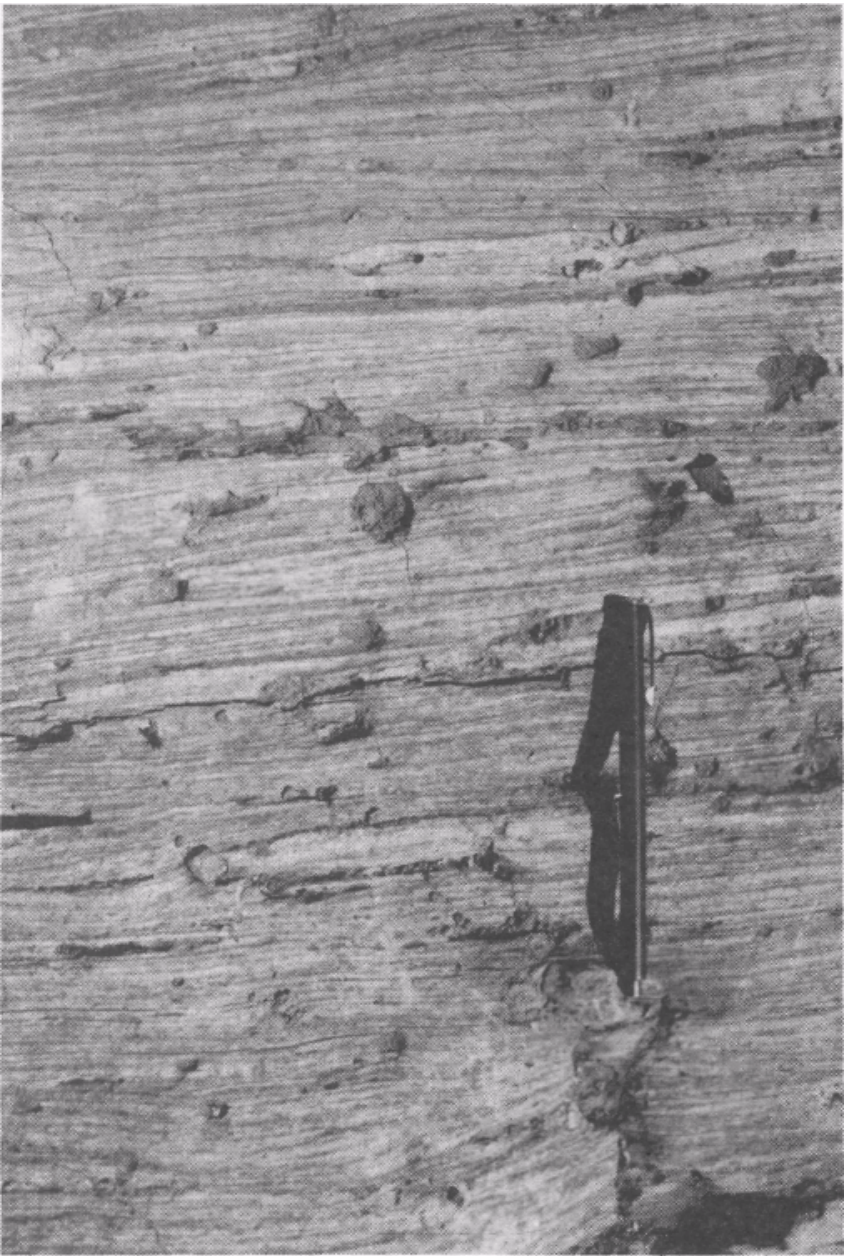

Foto 2 - Formação São Patricinho. Afloramento na estrada Itapací-Crixás, a sul do limite da área mapeada, expondo clorita-quartzo xisto com remanescentes de estruturas sedimentares, tais como laminação rítimica plano-paralela e cruzada. Os clastos são de quartzo e basalto (extremidade inferior do imã)

Photo 2 - São Patricinho Formation. Outcrop south of the study area, along the Itapací-Crixás dirt road, exposing a chlorite-quartz schist with relicts of sedimentary plane-parallel and cross laminations. The larger clasts consist of quartz and basalt (lower extremity of the magnet)

com magnetita e possuem até $10 \mathrm{~m}$ de espessura, extendendo-se por centenas de metros. Os protolitos são conglomerados oligomíticos suportados por matriz, com granules, seixos e blocos de quartzo leitoso e chert com pirita, magnetita ou hematita. A matriz é foliada e consiste de quartzo, sericita, hematita, magnetita e clorita.

Os muscovita xistos ocorrem em lentes de 2 a $15 \mathrm{~m}$ de espessura, no topo dos metaconglomerados basais e como intercalações centimétricas nas formações ferríferas. São rochas compostas por muscovita, subordinadamente cristais microscópicos de especularita.

Os metahidrotermalitos ocorrem como lentes com centenas de metros de comprimento e de 20 a $40 \mathrm{~m}$ de largura, na base da formação. As lentes são compostas por remanescentes de condutos de descarga exalativa, circundados por auréolas de alteração hidrotermal. Os primeiros são tubos circulares a elípticos, com 0,5 a 1,5 m de diâmetro, (Foto 5) formados por um núcleo de quartzo leitoso sacaróide envolto por turmalinito maciço, de granulação muito fina e estrutura radiada. As auréolas de alteração hidrotermal exibem três zonas que, do centro para a periferia, consistem de

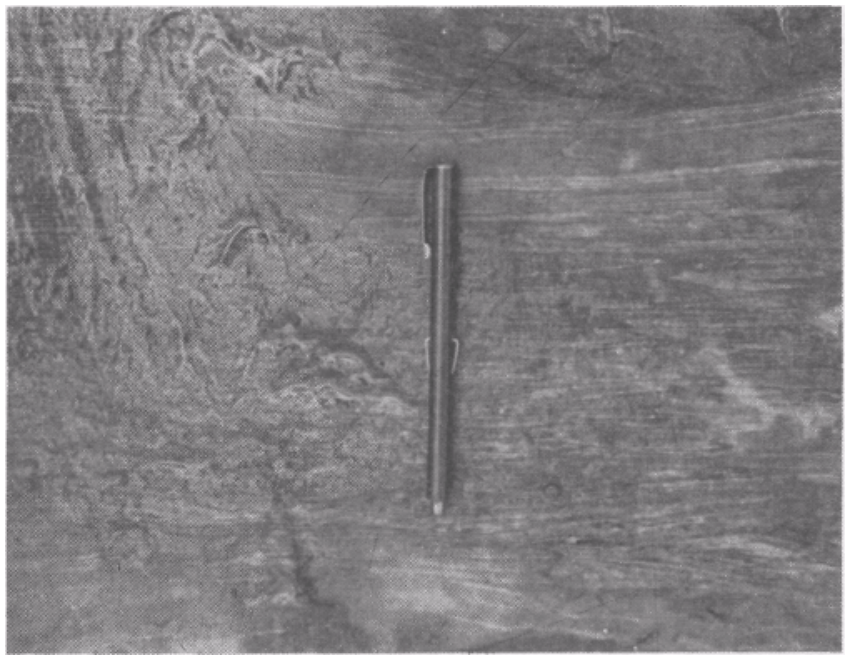

Foto 3 - Formação ferrífera bandada da Formação Aimbé. $O$ bandamento é dado pela alternância de níveis com hematita (bandas escuras) e muscovita (bandas claras)

Photo 3 - Banded iron formation of the Aimbé Formation. Banding is due to the alternation of haematite (dark bands) and muscovite (light bands)

protolitos metamorfizados para (a) cloritóide-cloritamagnetita-muscovita xisto, (b) clorita-muscovita-magnetita xisto, e (c) sericita xisto com proporções subordinadas de quartzo, clorita e turmalina.

Formação Cabaçal O Membro Inferior da Formação Cabaçal compreende filitos carbonosos, sericita xistos e ocasionais intercalações de chert, formações ferríferas e manganesíferas e metabasaltos. O Membro Superior consiste de sericita-quartzo-biotita xistos.

Os filitos carbonosos (Foto 6) são as rochas dominantes do Membro Inferior, onde ocorrem em pacotes com espessura aflorante não raro superior a $1000 \mathrm{~m}$. São rochas de cor preta e pulverulentas. Uma fina laminação dada pela alternância de níveis que se distinguem ora pelas proporções em

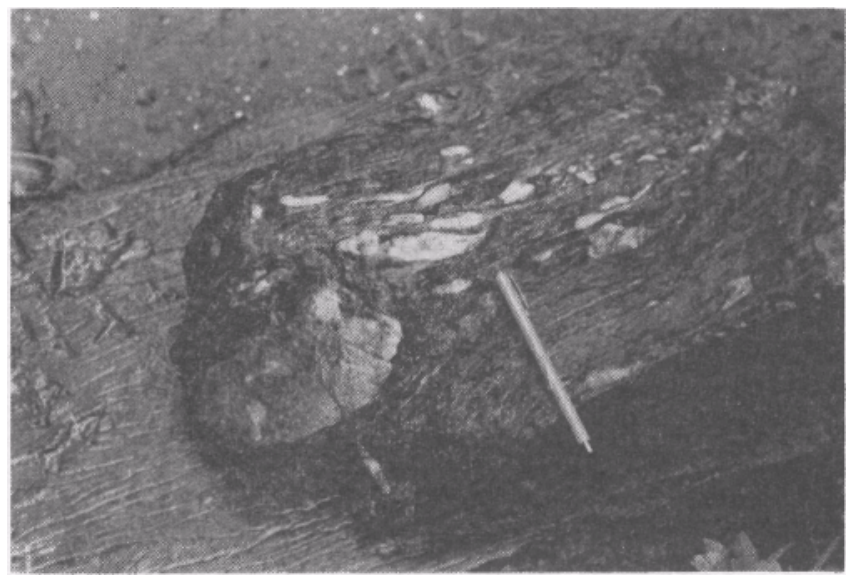

Foto 4 - Formação Aimbé. Metaconglomerado polimítico suportado por matriz. Os clastos maiores são de quartzo leitoso e chert com pirita (clasto maior à esquerda). A matriz contem sericita, clorita, quartzo, óxidos de ferro e epidoto

Photo 4 - Aimbé Formation. Polimictic, matrix supported metaconglomerate. The larger clasts are of milky quartz and pyrite-bearing chert (large clast in the left). The matrix consists of sericite, chlorite, quartz, iron oxides, and epidote 


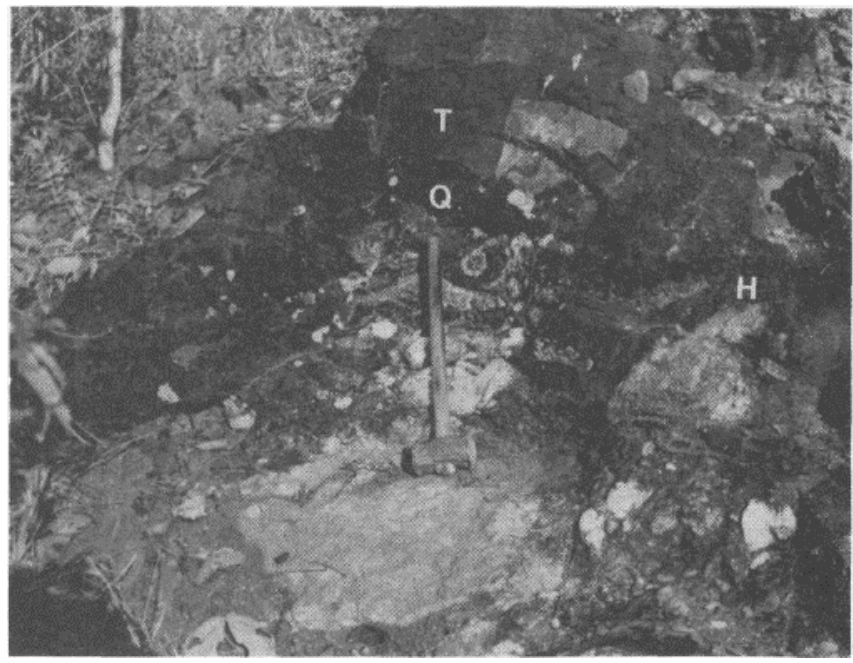

Foto 5 - Formação Aimbé. Exposição de cone exalativo mostrando um conduto com parede de turmalinito (T) com núcleo de quartzo leitoso $(Q)$, envolto por metahidrotermalito composto por magnetita, clorita e cloritóide $(H)$

Photo 5 - Aimbé Formation. Exposure of an exhalative cone consisting of a vent conduit with tourmalinite (microcrystalline schorlite) wall (T) with a milky quartz core $(\mathrm{Q})$, surrounded by a metahydrothermalite made up of magnetite, chlorite and chloritoid $(\mathrm{H})$

matéria carbonosa, ora pelas de quartzo, sericita e clorita, é a única estrutura primária remanescente nestas rochas e é visível tanto em afloramentos quanto em lâminas delgadas. A textura destas rochas é lepidoblástica muito fina, localmente granoblástica e porfiroblástica e seus constituintes principais são a sericita, clorita e o quartzo, mais raramente biotita e pirita. Granada, quando presente, ocorre preferencialmente em filitos carbonosos milonitizados.

A matéria carbonosa dessas rochas ocorre desde traços até cerca de $50 \%$ e comumente como microscópicas inclusões nos demais constituintes. Os resíduos carbonosos de diversas amostras, obtidos após pulverização e digestão com

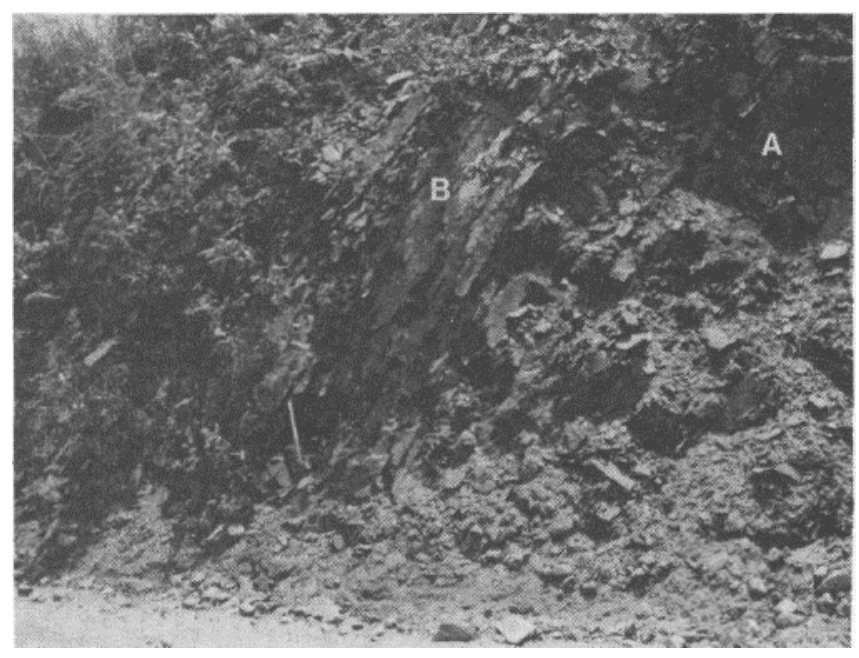

Foto 6 - Afloramento do Membro Inferior da Formação Cabaçal, expondo filito carbonoso (A) com intercalação de chert carbonoso (B). Estrada Guarinos-Crixás Photo 6 - Outcrop of the Lower Sub-Unit of the Cabaçal Formation, exposing a carbonaceous phyllite (A) with interlayered carbonaceous chert (B). Road from Guarinos to Crixás
$\mathrm{HF}$, e submetidos à difração de raios-X mostram um grau de cristalinidade incipiente se comparado com o da grafita, indicando matéria carbonosa parcialmente destilada por metamorfismo.

Sericita xistos ocorrem em camadas de espessura centimétrica até dezenas de metros, intercaladas em filitos carbonosos, com os quais comumente apresentam contatos gradacionais. Estas rochas possuem granulação fina, cor branca esverdeada, são homogêneas e não apresentam remanescentes de estruturas primárias. Ao microscópio exibem textura lepidoblástica e consistem de sericita, subordinadamente quartzo, opacos e, localmente, granada.

Meta-cherts, formações ferríferas e manganesíferas ocorrem em camadas maciças, bandadas ou laminadas, de granulação fina e espessura centimétrica a decamétrica. Os meta-cherts consistem de uma massa compacta de quartzo em mosaico, subordinadamente sericita, clorita, opacos e matéria carbonosa. $\mathrm{O}$ bandamento de meta-chert é primário quando dado pela variação nas proporções de seus constituintes minerais, o que retrata variações composicionais originais, mas é metamórfico quando dado por níveis de granulação variada que retratam diferentes graus de recristalização do quartzo.

As formações ferríferas e manganesíferas possuem textura granoblástica, subordinadamente poiquiloblástica e porfiroblástica. As primeiras consistem de quartzo e proporções variadas de magnetita, hematita ou grunerita As últimas contém quartzo e espessartita, parcial ou totalmente intemperizada para óxidos e hidróxidos de manganês.

Os raros metabasaltos intercalados nas porções basais do Membro Inferior ocorrem em camadas de espessura métrica a hectométrica e possuem cor verde escuro a claro, vermelho quando intemperizadas, granulação muito fina a fina e variam de foliadas a maciças. Em lâmina delgada, possuem textura nematoblástica fina, localmente granoblástica e porfiroblástica. Mineralogicamente não se distinguem dos metabasaltos da Formação Serra Azul, pois são constituídos por ferroactinolita e albita, subordinadamente clorita, epidoto, quartzo e opacos.

O Membro Superior da Formação Cabaçal consiste de uma associação de sericita-biotita-quartzo xistos de granulação muito fina, cores variáveis entre cinza escuro e branco quando não intemperizados e tons de amarelo quando alterados. Ao microscópio, posuem textura granoblástica a lepidoblástica, localmente porfiroblástica, muito fina, e são constituídos por proporções variadas de quartzo, sericita e biotita, subordinadamente granada, opacos e, localmente, também, anfibólio. Essas rochas são, em geral, laminadas a estratificadas e são ricas em vestígios de estruturas sedimentares. A laminação e estratificação é dada pela alternância rítmica de níveis que se distinguem pela granulação e pela composição mineral. A variação textural e composicional ao longo de ritmos individuais observados em lâminas delgadas sugerem que os protolitos eram leitos centimétricos a milimétricos de arenitos muito finos e siltitos, ambos impuros, e argilitos.

Por outro lado, estas rochas são ricas em relíquias de estruturas primárias tais como estratificação e laminação plano-paralela e cruzada, estruturas de corte-e-preenchimento e em chama. A estratificação e a laminação são dominantemente rítmicas (Foto 7) e, juntamente com a provável textura dos protolitos sedimentares, sugerem que o Membro Superior consiste predominantemente de metaturbiditos distais.

Localmente, o Membro Superior contem intercalações métricas de filitos carbonosos em íntima associação com metabasaltos komatiíticos. Estas rochas são mineralógica, textural e estruturalmente similares, respectivamente, aos filitos carbonsos do Membro Inferior da Formação Cabaçal e aos metabasaltos komatíticos intercalados nas demais 

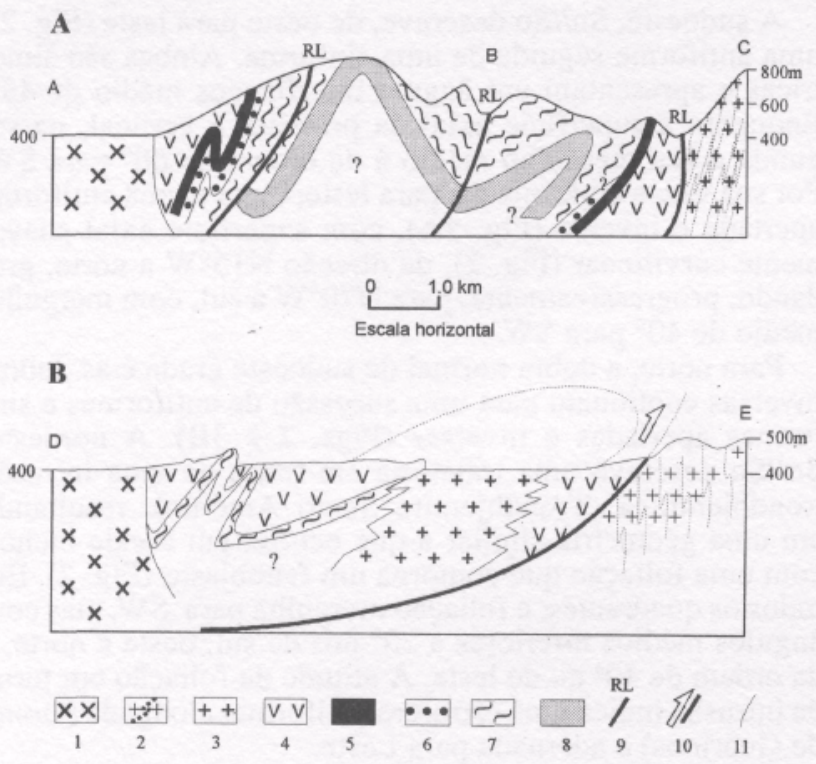

Fig 3 - Seções transversais ao greenstone belt de Guarinos mostrando as principais feições estruturais relacionadas com Dn+1. Localização das seções como mostrado na figura 2. As dobras esquematizadas são de Sn//So. Símbolos: 1 - Tonalito intrusivo do Complexo Caiamar; 2 - Gnaisses do Bloco Moquém; 3 - Trondhjemito Santo Antônio; 4 - Formação Serra Azul (metabasaltos com intercalações de formações ferríferas e manganesíferas); 5 - Formação São Patricinho (rochas metassedimentares e metatufos básicos); 6 - Formação Aimbé (formações ferriferas, metaconglomerados e metahidrotermalitos); 7 - Membro Inferior da Formação Cabaçal (filitos carbonosos com raras formações ferriferas e manganesifferas); 8 - Membro Superior da Formação Cabaçal (meíaturbiditos distais); 9 - Rampas laterais de falhas de empurrão relacionadas a Dn; 10- Falhas de empurrão relacionadas a Dn+1; 11 Contatos

Fig 3 - Cross-sections of the Guarinos greenstone belt showing the main structural features related to $\mathrm{Dn}+1$. Loccation of sections shown in figure 2. Folds shown in the sections are delineated by SruYSo. Simbols are as follows: 1 - intrusive tonalite of the Caiamar Complex; 2 - Gneisses of the moquém Block; 3 - Santo Antônio trondhjemite; 4 - Serra Azul Formation (metabasalts with minor intercalations of banded iron or manganese formations); 5 - São Patricinho Formation (metassedimentary and basic metatuffaceous rocks); 6 - Aimbé Formation (banded iron formation, metaconglomerates, and metahydrothermalites); 7 - Lower Member of the Cabaçal Formation (carbonaceous phyllites with rare banded iron or manganese formations); 8 - Upper Member of the Cabaçal Formation (distal metaturbidites); 9 - Lateral ramps of Dn thurst faults; 10 - Dn+1 thrust faults; 11 - Contacts.

vulcânicas básicas da Formação Serra Azul. É, ainda, incerto se representam repetições tectônicas de níveis estratigráfícos inferiores ou se recorrências de ambiente euxênico associado a um episódio vulcânico básico estratigraficamente mais elevado.

ARCABOUÇO ESTRUTURAL As feições e a evolução estruturais do greenstone belt de Guarinos estão sendo objeto de estudos em andamento. Até o presente, as feições estruturais sugerem que a evolução estrutural das supracrustais ocorreu em pelo menos dois estágios principais. Ambos estágios contém evidências de uma progressão de fases iniciais de deformação dúctil para fases subsequentes de deformação rúptil. Enquanto a primeira se traduz pela formação de dobras e feições associadas, a segunda se manifesta por falhas de empurrão. Apenas para efeitos descriti-

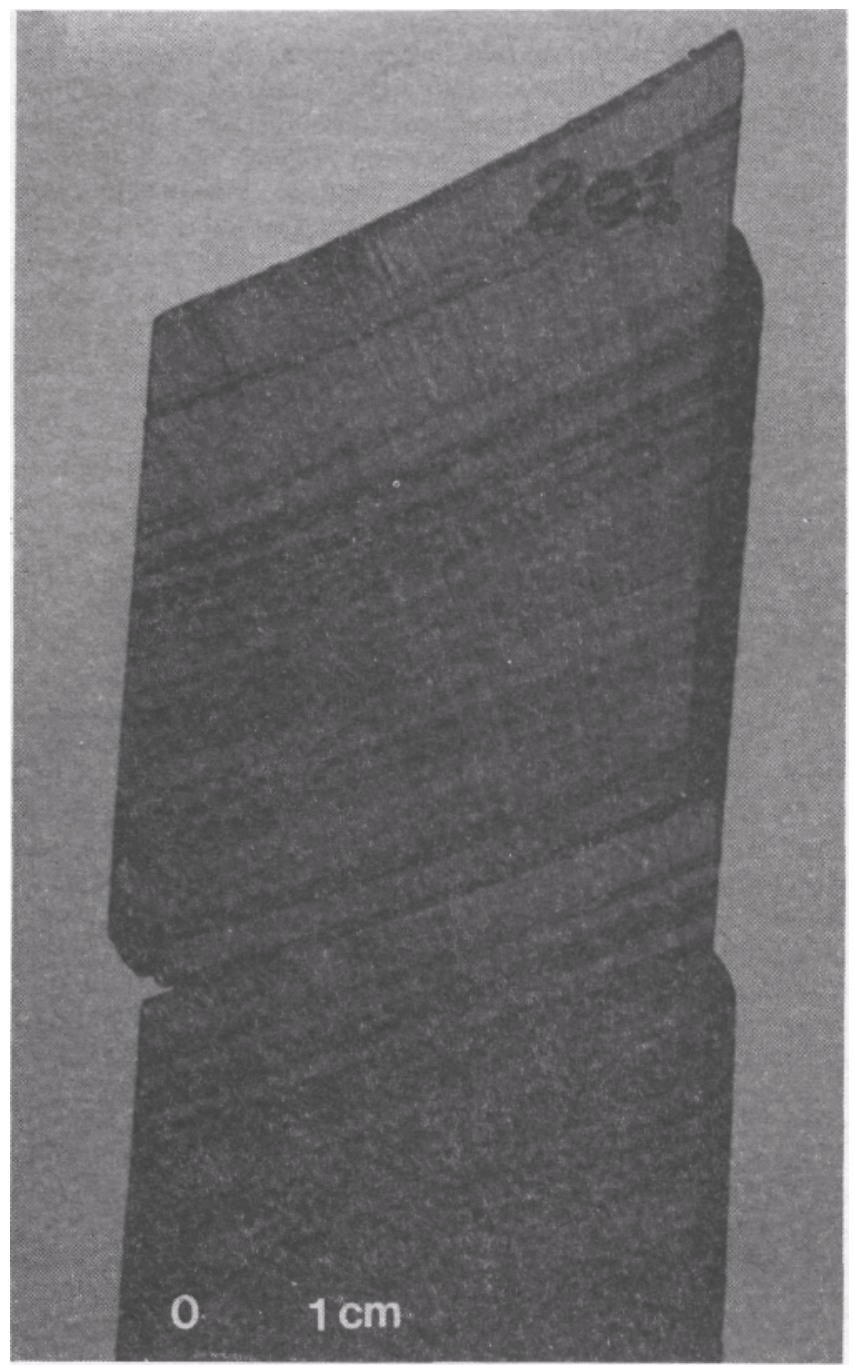

Foto 7 - Amostra polida do Membro Superior da Formação Cabaçal mostrando metassiltitos e metafolhelhos ritmicamente acamadados

Photo 7 - Polished sample of the Upper sub-unit of the Cabaçal Formation with rythmically laminated metasiltite and metashale

vos, as duas fases principais de deformação serão designadas, nos parágrafos seguintes, como $\mathrm{Dn}$ e $\mathrm{Dn}+1$. As relações temporais entre ambas fases são ainda incertas. As relações espaciais entre Dn e Dn+1 podem ser deduzidas mediante a combinação do mapa geológico da figura 2 com as seções transverais da foto 7 .

Fase Dn A primeira fase de deformação do greenstone belt de Guarinos ocorreu após a deposição das rochas supracrustais. $\mathrm{O}$ estágio dúctil desta deformação é caracterizado pela formação de uma xistosidade (Sn), sempre disposta paralela ao acamamento (Só), indicando uma generalizada transposição de Só devido à formação de dobras apertadas a isoclinais. Por interferência da segunda fase de deformação, a direção média de $\mathrm{Sn} / / \mathrm{So}$ é $\mathrm{N} 15^{\circ} \mathrm{W}$ e o mergulho, em média $35^{\circ}$, é ora para SW ora para NE (Fig. 2).

As lineações associadas são barras de quartzo e mullions, comuns em rochas metassedimentares, lineações minerais dadas por agulhas de actinolita em metabasaltos, e eixos de dobras isoclinais em rochas metassedimentares. Essas lineações ora são horizontais e ora apresentam caimento, no máximo de $15^{\circ}$, para NNW ou SSE. 
A posição estruturalmente elevada dos metaconglomerados e centros exalativos basais às formações ferríferas da Formação Aimbé, estruturalmente mais baixas (Resende 1994), e as relações de topo e base determinadas a partir de estruturas sedimentares primárias reliquiares da Formação Cabaçal, indicam que a Fase Dn foi responsável pela inversão estratigráfica completa das supracrustais.

A caráter alóctone da faixa de supracrustais é atribuído ao estágio de deformação rúptil ocorrido durante Dl, subseqüente e em continuidade à deformação dúctil. $\mathrm{O}$ estágio rúptil é identificado por falhas que originaram a ruptura de flancos de dobras, a delaminação de estratos e o desenvolvimento de zonas de descolamento.

As falhas se evidenciam por zonas de milonitos e ultramilonitos. Filetes, boudins e veios de quartzo leitoso paralelos à foliação milonítica, são comuns nestas falhas e alguns veios contém disseminações de arsenopirita, pinta, calcopirita e ouro, como nos garimpos a sul de Guarinos e na Mina Serra Formosa, a norte. Algumas falhas contem, além de milonitos e veios quartzo, também pequenas lentes e blocos imbricados de quartzito com sillimanita e granada e gnaisses graníticos, indicando um envolvimento de rochas mais profundas do que o observado nas demais falhas e sugerindo que estas podem representar zonas principais de descolamento.

As falhas associadas com Dn são sempre direcionais (Fig. 2), subparalelas a ligeiramente diagonais à foliação metamórfica e são responsáveis pela escamação e repetições estratigráfícas no interior das supracrustais. Essas falhas estão confinadas às rochas do Grupo Guarinos, são obliteradas pelo Grupo Araxá a sul, e não se propagam para o interior dos gnaisses do Bloco Moquém, a leste, e do Complexo Caiamar, a oeste.

As falhas têm direção média $\mathrm{N} 10^{\circ} \mathrm{W}$, mergulho da ordem de $30^{\circ} \mathrm{SW}$ e apresentam uma lineação de estiramento que é ora horizontal e paralela à direção da foliação milonítica, ora apresenta duplo caimento, de no máximo de $15^{\circ}$, tanto para NW quanto para SE. Indicadores cinemáticos mostram que as falhas direcionais da porção oeste são sinistrais, e as de leste, incluindo a falha do limite meridional das supracrustais com o Bloco Moquém, são dextrais. O paralelismo entre estas falhas e $\mathrm{Sn} / / \mathrm{So}$, a direção dos eixos de dobras parasitas e as lineações mineral e de estiramento nas supracrustais sugere que as mesmas são rampas de escamas de empurrão e que as dobras associadas, originalmente ortogonais à direção de transporte, foram rotacionadas paralelamente a esta durante a carreação tectônica. A orientação comum destas falhas e os movimentos sinistrai a oeste e dextral a leste, indicam que o transporte tectônico durante o estágio rúptil de Dn ocorreu de sul para norte.

Do exposto conclue-se que a fase Dn de deformação do greenstone belt de Guarinos ocorreu sob regime compressivo. O estágio inicial de Dn envolveu a formação de dobras apertadas, transposição e metamorfismo regional e evoluiu para um estágio final quando se formaram falhas de empurrão com vergência norte.

A idade de Dn é incerta. Contudo, considerando que tonalitos do Complexo Caiamar possuem uma idade mínima de 2.9 Ga (Tassinari \& Montalvão 1980, Montalvão 1985), que estes intrudiram as supracrustais de Guarinos com formação de auréolas de metamorfísmo de contato em metabasaltos da Formação Serra Azul e atingiram as supracrustais já deformadas e metamorfisadas durante Dn, a idade dessa deformação é, no mínimo, penecontemporânea ao evento de intrusões tonalíticas.

Fase Dn+1 Dobras do segundo estágio estão delineadas pelo dobramento de Sn//So (Fig. 3). A geometria e posição espacial das dobras desta fase variam regionalmente.
A sudoeste, Sn//So descreve, de oeste para leste (Fig. 2), uma antiforme seguida de uma sinforme. Ambas são simétricas e apresentam um ângulo interflancos médio de $45^{\circ}$. Enquanto a superfície axial da primeira é vertical, na segunda o seu mergulho médio é da ordem de $60^{\circ}$ para SW. Por sua vez, a sinforme dá, para leste, lugar a uma antiforme apertada e inversa (Fig. 3A), com superfície axial suavemente curvilinear (Fig. 2), de direção $\mathrm{N} 15^{\circ} \mathrm{W}$ a norte, gradando, progressivamente, para $\mathrm{N} 70^{\circ} \mathrm{W}$ a sul, com mergulho médio de $40^{\circ}$ para SW

Para norte, a dobra normal de sudoeste grada e as dobras inversas continuam para uma sucessão de antiformes e sinformes apertadas e inversas (Figs. 2 e 3B). A nordeste, $\mathrm{Sn} /$ /So descreve uma trajetória em torno de uma intrusão trondhjemítica (Trondhjemito Santo Antônio), resultando em uma geometria similar a que ocorre, em escala menor, com uma foliação que contorna um fenoblasto (Fig. 2). Em todos os quadrantes, a foliação mergulha para SW, mas com ângulos médios inferiores a $20^{\circ}$ nos de sul, oeste e norte, e da ordem de $40^{\circ}$ no de leste. A atitude da foliação em torno da intrusão indica uma estrutura antiformal alongada (Domo de Guarinos) e adernada para Leste.

Em toda região, a superfície axial das dobras associadas com $\mathrm{Dn}+1$ é uma crenulação $(\mathrm{Sn}+1)$ de Sn.muito freqüente em rochas metassedimentares detríticas, particularmente filhos carbonosos, mas rara em rochas metavulcânicas. Em porções menos deformadas, $\mathrm{Sn}+1$ evolui para uma clivagem espaçada, com a qual freqüentemente se associam dobras parasitas de zona axial de dimensões decimétricas e geometria en chevron. A lineação resultante da intersecção de $\mathrm{Sn}+1$ com $\mathrm{Sn} / / \mathrm{So}$ e as charneiras das dobras en chevron possuem duplo caimento, em média de $10^{\circ}$, para sul e norte.

Lineações minerais, de estiramento, de intersecção e charneiras de dobras formadas durante $\mathrm{Dn}+1$ são comuns em toda a região. As primeiras são representadas por agulhas de actinolita em metabasaltos e hematita acicular em formações ferríferas. As lineações de estiramento consistem de barras de quartzo em rochas metassedimentares. As lineações mineral e de estiramento predominam a norte e sudoeste, são paralelas entre si e estão postadas segundo o mergulho das superficies axiais das dobras regionais, com caimento médio da ordem de $40^{\circ} \mathrm{SW}$. A sua freqüência cresce em direção a zonas de descolamento marcadas por estreitas faixas de milonitos. As lineações de interseção são abundantes a sudoeste, possuem duplo caimento médio de $10^{\circ}$ para sul e são paralelas às charneiras de dobras parasitas. Aqui, as lineações minerais e de estiramento são mais escassas e, a exemplo das porções norte e leste, também estão orientadas segundo o mergulho das superfícies axiais.

Por conseguinte, as dobras de $\mathrm{Dn}+1$ são coaxiais com as de Dn,. Contudo, as dobras associadas a Dn+1 contrastam com as de Dn por um ângulo interflancos mais aberto, menor intensidade de transposição, ausência de recristalizações penetrativas e de superfícies axiais metamórficas, e pela orientação das lineações de estiramento segundo o mergulho.

Em torno do trondhjemito Santo Antônio, as rochas que o contornam são apenas metabasaltos da Formação Serra Azul. A lineação mais proeminente nos metabasaltos é mineral, dada pela orientação de diminutas agulhas de anfibólio. As agulhas estão normalmente orientadas segundo três direções, sendo uma anelar, outra radial e uma diagonal, orientada segundo $\mathrm{N} 30^{\circ} \mathrm{E}$. Enquanto as duas primeiras podem ser explicadas por encurvamento e rotação de lineações minerais precedentes durante a intrusão. A relação entre a terceira e a estrutura local é ainda incerta, mas a sua ocorrência restrita ao domínio nordeste implica que a mesma deve ter se originado durante a formação da estrutura local.

A posição estruturalmente elevada dos metaconglo merados e centros exalativos basais às formações ferríferas da 
Formação Aimbé, estruturalmente mais baixas, e as relações de topo e base determinadas a partir de estruturas sedimentares primárias reliquiares da Formação Cabaçal, mostram que (i) a sudoeste, a base do Grupo Guarinos se situa, sempre, em posições estruturais elevadas, indicando que a estrutura antiformal normal é uma sinclinal inversa, (ii) a leste, norte e nordeste, os flancos de antiformes voltados para oeste tem estratigrafía inversa e os voltados para leste são normais.

Em geral, a frequência das dobras parasitas e intensidade da crenulação $(\mathrm{Sn}+1)$ cresce em direção a zonas de milonitos de atitude média $\mathrm{N}-\mathrm{S} / 40^{\circ} \mathrm{W}$, indicando que $\mathrm{Dn}+1$ também foi acompanhado de delaminação rúptil. A formação de superfícies de descolamento é mais evidente a nordeste, onde uma falha direcional dextral, de direção $\mathrm{N} 60^{\circ} \mathrm{E}$ e mergulho vertical, corta o Grupo Guarinos ddiagonalmente, próximo e logo a norte de Guarinos. Para nordeste, o seu traço gradualmente adquire direção NS, passando para N30 e $\mathrm{N} 45^{\circ} \mathrm{W}$ e com mergulho de $45^{\circ}-50^{\circ} \mathrm{W}$, quando, então, define o contato entre as supracrustais e o Bloco Moquém, adquirindo uma lineação de estiramento segundo o mergulho. Para Jost et al. (1994) as relações geométricas e cinemáticas entre o segmento NE e seu encurvamento gradual para norte e noroeste sugerem a combinação, respectivamente, de rampas lateral e frontal de uma falha de empurrão, com vergência para leste. Neste caso, a estrutura de domo adernado é uma dobra de arrasto associada à falha de empurrão e em cujo núcleo se alojou a intrusão trondhjemítica, a exemplo do que ocorreu em outras áreas descritas por Jost et al. (1990) na região arqueana de Crixás.

A interferência de Dn+1 sobre Dn fornece a idade relativa entre ambas, mas a idade da primeira é mais incerta que a da segunda. O quadro geológico regional mostra que a região de Crixás está exposta como janela no interior de rochas metassedimentares do Proterozóico, particularmente do Grupo Araxá. Os terrenos mais jovens são alóctones e seu transporte tectônico mostra uma vergência para leste, coincidindo com a vergência sugerida por indicadores cinemáticos de $\mathrm{Dn}+1$ em supracrustais arqueanas de Guarinos. Esta coincidência, no entanto, não é suficiente para indicar que $\mathrm{Dn}+1$ seja de idade proterozóica. Assim como é possível atribuir a construção das estruturas desta fase aos episódios brasilianos, também é viável interpretá-las como efeito do diapirismo dos complexos granito-gnaissicos adjacentes. Uma provável evidência para tanto é a intrusão trondhjemítica do núcleo do domínio nordeste, se esta puder ser correlacionadao ao evento magmático arqueano, responsável pela associação TTG regional. A idade de $\mathrm{Dn}+1$ é, portanto, inteiramente especulativa.

METAMORFISMO Três tipos de metamorfismo afetam as rochas do Grupo Guarinos. Esses compreendem (a) metamorfismo regional, (b) termal no contato com o Tonalito Tocambira (Complexo Caiamar) e com o Trondhjemito Santo Antônio, e (c) metamorfismo dinâmico em zonas de falha.

Metamorfismo Regional As associações minerais desse metamorfismo em rochas da porção setentrional do greenstone belt de Guarinos contém actinolita, talco e clorita em rochas ultramáficas; albita, quartzo, epidoto e ferroactinolita em metabasaltos; quartzo, clorita, sericita, e, localmente, granada e biotita em rochas metassedimentares elásticas; muscovita ou quartzo e magnetita, hematita ou espessartita em rochas metassedimentares químicas, e turmalina, quartzo, clorita, cloritóide, muscovita e magnetita em metahidrotermalitos. As paragêneses em metaultramáficas, metabasaltos e metapelitos indicam fácies xisto verde. Os equilíbrios minerais foram alcançados nas zonas da clorita, biotita e granada, mas não é, ainda, possível definir o sentido da polaridade metamórfica.
Dentre as lentes tectonicamente imbricadas no Grupo Guarinos, os quartzitos com silimanita (fíbrolita) e granada indicam fácies anfibolito. As demais possuem paragêneses da fácies anfibolito, com retrometamorfísmo para a fácies xisto verde.

Metamorfismo Termal Os efeitos termais de uma intrusão tonalítica do Complexo Caiamar (Tonalito Tocambira) sobre metaultramáficas e metabasaltos do Grupo Guarinos compreendem (i) a formação de hornblenda e plagioclásio, superimpostos à paragênese de metamorfismo regional, (ii) neoformação de granada e quartzo, a partir de anfíbólio e plagioclásio, e (iii) recristalização de actinolita, carbonato e talco em rochas ultramáficas.

Os efeitos de contato da intrusão trondhjemítica da porção nordeste da área sobre os metabasaltos compreendem (i) neoformação de albita, carbonato e epidoto; (ii) recristalização e endurecimento dos metabasaltos e (iii) injeção de apófises e veios pegmatóides na foliação metamórfica dos metabasaltos. As paragêneses de metamorfismo de contato nos metabasaltos são fácies albita-epidoto hornfelse.

Metamorfismo Dinâmico Os milonitos e ultramilonitos das zonas de falha mostram feições comuns de zonas de cisalhamento, tais como redução de tamanho de grão, estiramento mineral, sombras de pressão e neoformação mineral. A matriz cominuida dos milonitos está totalmente recristalizada, permitindo considerá-los como blastomilonitos. As paragêneses neoformadas variam com os protolitos, mas são comparáveis com as condições da fácies xisto verde do metamorfismo dinamotermal. Alteração hidrotermal simultânea com a formação de milonitos são por vezes notáveis, como exemplifica a zona de cisalhamento onde se situam garimpes de ouro, a sul de Guarinos (Pulz 1990).

RECURSOS MINERAIS Recursos minerais na área mapeada compreendem:

(a) Ouro, em dois modos de ocorrência: (i) em zonas de cisalhamento, como os garimpes a sul de Guarinos (Maria Lázara e outros), descritos por Ribeiro Filho (1984), Pulz (1990), Pulz et al (1991a, 1991b), e os depósitos recentemente descobertos da Mina Serra Formosa, a norte de Guarinos e (ii) cacalheiros aluviais, como ao longo do Rio Caiamar, na porção norte da faixa do Grupo Guarinos,

(b) Formações ferríferas com magnetita e/ou hematita, (i) intercaladas em metaultramáficas e metabasaltos; (ii) como unidades estratigráficas, tais como a Formação Aimbé (Resende et al 1993, Resende 1994, Jost et al 1994c, Resende \& Jost 1994), e (iii) interestratificadas em metassedimentos carbonosos da Formação Cabaçal,

(c) Formações manganesíferas interestratificadas com metassedimentos carbonosos da Formação Cabaçal.

CONCLUSÕES O maior volume de rochas da porção setentrional do greenstone belt de Guarinos consiste de metavulcânicas básicas e metassedimentos elásticos, subordinadamente químicos e, mais raramente, prováveis komatiitos. As relíquias de estruturas primárias em metabasaltos e metassedimentos indicam que o vulcanismo e a sedimentação foram subaquáticos e não há, até o presente, evidências de regimes subaéreos.

A continuidade lateral e variação da espessura dos derrames básicos indica que a Formação Serra Azul consiste de unidades de fluxo, cada unidade compreendendo uma sucessão de extensos derrames de espessuras métricas a decamétricas. A raridade de intercalações de rochas metassedimentares químicas nos metabasaltos sugere que os períodos de vulcanismo foram prolongados, originando espessas unidades de fluxo, seguidos de curtos períodos de quiescência.

As estruturas sedimentares reliquiares em metas-sedimentos sugerem que o ambiente deposicional, apesar de 
continuamente subaquático, se caracterizou por variada energia no tempo, aliada a diferentes regimes tectônicos. $\mathrm{O}$ regime sedimentar inicial produziu ritmitos, mas não necessariamente turbiditos, como sugerem os metassedimentos da Formação São Patricinho. A Formação Aimbé representa um prolongado período de quiescência da sedimentação detrítica, associado a um pulso tectônico, com formação de falhas gravitacionais, basculamento da pilha toleiítica e sedimentar subjacente, seguido da instalação de um sistema convectivo, com descarga hidrotermal controlada por falhas e volumosa deposição de formações ferríferas. A ausência, até o presente, de rochas vulcânicas na Formação Aimbé sugere que a mesma é uma unidade exalativa sedimentar. A sedimentação química foi gradualmente substituída por espessa sedimentação anóxica, com proliferação de microrganismos, localmente exalativa, em regime de baixa energia. $\mathrm{O}$ ambiente anóxico foi subitamente sufocado por uma sedimentação terrígena rítmica, eventualmente depositada sobre uma discordância erosiva.

Dados geoquímicos preliminares sobre as rochas metassedimentares detríticas do Grupo Guarinos apresentados por Jost et al (1993), sugerem uma proveniência a partir de misturas de detritos de áreas fontes com rochas básicas e ultrabásicas, subordinadamente félsicas.

As rochas do Grupo Guarinos estruturam, a sul, um antiforme normal que, para norte e leste, progressivamente se aderna, gerando um antiforme inverso. Estruturas primá- rias em metavulcânicas e em metassedimentos detríticos e químicos mostram que a seqüência estratigráfíca do Grupo Guarinos está inteiramente invertida. Isto indica que grande parte da tectônica e da complexidade estratigráfíca do grupo está relacionada com a formação de nappes, sendo, por conseguinte, um segmento crustal alóctone. $\mathrm{O}$ reequilíbrio mineral durante a deformação principal das rochas do Grupo Guarinos ocorreu sob condições da fácies xisto verde, provavelmente cobrindo o espectro da zona da clorita até a zona da granada.

As rochas do Grupo Guarinos foram intrudidas a oeste por tonalitos e, no seu interior, por trondhjemitos, ambos com formação de auréola de metamorfismo de contato. Ambas intrusões ocorreram quando as rochas supracrustais já haviam sido deformadas e metamorfizadas. A idade Rb/ Sr mínima de 2,9 Ga (Tassinari \& Montalvão 1980, Montalvão 1985, Vargas 1992), sugere que tanto o tonalito quanto as supracrustais possam ser mais velhas do que até então sugerido.

Agradecimentos Os recursos para realização dos trabalhos de campo e laboratório do presente projeto foram providos pela Universidade de Brasília. H. Jost e R.M. Kuyumjian agradecem ao Conselho Nacional de Desenvolvimento Científico e Tecnológico - CNPq, pelas Bolsas de Pesquisador.

\section{REFERÊNCIAS BIBLIOGRÁFICAS}

ALMEIDA, F.F.M. de. 1968. Evolução tectônica do Centro-Oeste Brasileiro no Proterozóico Superior. Academia Brasileira de Ciências, Anais, Suplemento 40:285-296.

DANNI, J.C.M. \& RIBEIRO, C.C. 1978. Caracterização estratigráfíca da seqüência vulcano-sedimentar de Pilar de Goiás e de Guarinos, Goiás. In: CONGRESSO BRASILEIRO DE GEOLOGIA, 30. Recife, 1978. Anais...Recife, SBG, 2:252-269.

DANNI, J.C.M.; JOST, H.; WINGE, M. \& ANDRADE, G.F. 1986. Aspectos da evolução de terrenos granito-greenstone: exemplo da região de Hidrolina, GO. in SBG, XXXIV CONGR. BRASILEIRO DE GEOLOGIA, Goiânia, 1986, Anais..., Goiânia, 2:570-584.

JOST, H. \& OLIVEIRA, A.M. 1991. Stratigraphy of the greenstone belts of the Crixás region, Goiás, Central Brazil. Journal of South American Earth Sciences, 4(3):201-214.

JOST, H. \& FERREIRA FILHO, CF. 1987. Geologia da região meridional do greenstone belt de Guarinos, GO. Instituto de Geociências, Universidade de Brasília. Relatórios de Graduação inéditos

JOST, H.; OLIVEIRA, A.M. \& VARGAS, M.C. 1992. Petrography, geochemistry, and structural control of trondhjemitic intrusions in greenstone belts of the Crixás region, Central Brazil - Sociedade Brasileira de Geologia, XXXVII Congr. Brasileiro de Geologia, São Paulo, Resumos Expandidos, 1:43-44.

JOST, H.; KUYUMJAN, R.M. \& SILVA, C.A. 1993. Características geoquímicas e a proveniência dos metassedimentos arqueanos do Grupo Guarinos, GO. In: CONGRESSO BRASILEIRO DE GEOQUIMICA, 4, Brasília, 1993, Resumos Expandidos.... Brasília, SBGq, p. 109-112.

JOST, H.; VARGAS, M.C.; FUCK, M.C.; KUYUMJAN, R.M. \& PIRES, A.C.B. 1994a. Relações de contato, litologias, geologia estrutural e geofísica do bloco arqueano do Moquém, Crixás, Goiás. IN: SIMPOSIO DE GEOLOGIA DO CENTRO-OESTE, 4. Brasília, 1994. Resumos Expandidos... Brasília, SBG, Núcleo Centro Oeste, p. 21-23.

JOST, H.; CARMELO, A.C. \& MENESES, P.R. 1994b. Litologias, relações de contato e estrutura do Bloco Caiamar, Crixás, Goiás. IN: SIMPÓSIO DE GEOLOGIA DO CENTRO-OESTE, 4. Brasília, 1994. Resumos Expandidos... Brasília, SBG, Núcleo Centro Oeste, p. 18-20.

JOST, H.; RESENDE, M.G. \& SILVA, C.A. 1994c. Redefinição estratigráfíca e litológica da Formação Aimbé, Grupo Guarinos, GO - IN: SIMPÓSIO DE GEOLOGIA DO CENTRO-OESTE, 4. Brasília, 1994. Resumos Expandidos... Brasília, SBG, Núcleo Centro Oeste, p. $11-14$.

MONTALVÃ்O, R.M.G. 1985. Evolução geotectônica dos terrenos granitóides-greenstone belts de Crixás-Guarinos-Pilar de Goiás-Hidrolina (Goiás). 372 pp. (Tese de Doutoramento, IG/USP).
PULZ, G.M. 1990. Geologia do depósito aurífero tipo Maria Lázara (Guarinos, Goiás). 139 pp (Dissertação de Mestrado, IG/UnB).

PULZ, G.M.; JOST, H. \& FUCK, R.A. 1991a. Formação do ponto tríplice e interação fluido/rocha constituem aspectos chaves na proșpeção de depósitos auríferos tipo Maria Lázara (Goiás). In: SIMPOSIO DE GEOLOGIA DO CENTRO-OESTE, 3. Cuiabá, 1991. Anais... Cuiabá, SBG, p. 84-91.

PULZ, G.M.; JOST, H.; GIULIANI, G. \& MICHEL, D. 1991b. The Archean Maria Lázara gold deposit, Goiás, Brasil: example of Au$\mathrm{Bi}-\mathrm{Te}-\mathrm{S}$ metallogeny related to shear zones intruded by sinkynematic granitoids. In Symposium Brasil Gold 91, Belo Horizonte, 1991, Proceedings... Rotterdam, Balkema, p. 385-387.

RESENDE, M.G. 1994. Geologia e Petrologia da Formação Aimbé, Grupo Guarinos, Goiás. 128 pp (Dissertação de Mestrado, IG/UnB).

RESENDE, M.G. \& JOST, H. 1994. Geoquímica e química mineral dos litotipos da Formação Aimbé, Grupo Guarinos, GO - IN: SIMPÓSIO DE GEOLOGIA DO CENTRO-OESTE, 4. Brasília, 1994. Resumos Expandidos... Brasília, SBG, Núcleo Centro Oeste, p. 15-17.

RESENDE, M.G.; JOST, H.; SILVA, C.A; VIEIRA, A.C. \& SILVA, C.M. 1993. Aspectos geoquímicos dos exalitos da Formação Aimbé, Grupo Guarinos, GO IN: CONGRESSO BRASILEIRO DE GEOQUÍMICA, 4. Brasília, 1993. Anais... Brasilia, SBGq., p. 133-135.

RIBEIRO FILHO, W. 1984. Geologia e alguns aspectos das mineralizações auriferas das faixas Pilar e Guarinos. In: ENCONTRO REGIONAL DO OURO DE GOIÁS, I, Goiânia, 1984. Aníiíí...Goiânia, SBG, p. 06-24.

SABÓIA, L. A. 1979. Os greenstone belts de Crixás e Goiás, GO. Goiânia, SBG, Boletim Informativo, 9:43-72.

TASSINARI, C.G.C. \& MONTALVÃO, R.M.G. 1980. Estudo geocronológico do greenstone belt de Crixás, GO. In: CONGRESSO BRASILEIRO DE GEOLOGIA, 31, Camboriú, 1980. Anais... Camboriú, SBG, 5:2752-2759.

VARGAS, M.C. 1992. Geologia das rochas granito-gnáissicas da região de Crixás, Guarinos, Pilar de Goiás e Hidrolina, Goiás. 167 pp (Dissertação de Mestrado, IG/UnB).
MANUSCRITO A831 Recebido em 02 de março de 1995 Revisão do autor em 15 de dezembro de 1995 Revisão aceita em 20 de dezembro de 1995 